Barbara SZYKula-Piec

The Main School of Fire Service

in Warsaw, Poland

\title{
SOCIETAL RESILIENCE IN THE ERA OF HAZARDS. THE CASE STUDY OF AN EXAMPLARY COMMUNITY
}

The old world has fallen, and the new one, one created after the pandemic, has not been born yet.It is now the time of uncertainty, but concurrently also a timeof new openings in all areas of human life

\section{Abstract}

GoAL:

The present pandemic situation has revealed system imperfections and gaps in holistic management of societal resilience. Yet it should be borne in mind that the catalogue of potential hazards is extensive and comprises an entire spectrum of threats that affect the functioning of societies. Safety management is a specific process, which should take into account building societal resistance based on flexibility and elasticity of its components. The goal of the paper is to present resilience indices/measures with coexistence of stability and change as well a specific homeostasis accompanied by dynamic evolution that guarantees sustainable development.

\section{METHOD:}

Methodology based on approaches adopted among others by the United Nations University Institute for the Advanced Study of Sustainability 
(UNU-IAS)-SEPLS and selected literature sources allowed the establishment of a set of criteria meant to assist in compilation of input data for needs of analyses of mesoregions. In addition results of the research process were verified/subjected to testing during interviews carried out among community members and representatives of local authorities. All those materials were analysed in a synthetic manner and allowed achieving the assumed goal.

\section{RESULTS:}

A developed catalogue of indices that may be used to measure local societal resilience aimed at facilitating the identification of shortcomings in security systems, subsystems and entities assigned with the implementation of tasks for the sustainable development of the community. According to the sociological approach, based on the theory of community development and trust culture as well as on an approach assuming the concept of system resilience, a wide set of indicators has been established which form a starting point for further studies in this field. The deliberations took into account not only a subjective perception of security, but also its measurable variables.

\section{Discussion:}

The paper has both a theoretical and a practical dimension, which may be useful in further stages of academic research and in utilitarian implementation in the security management process. The concept of resilience is quite effective under the general theory of systems. However, in situations when systemic formulations tens to hinder rather than help provide clarifications, a different interpretation may be justified. This may happen in case of building societal resistance, limiting the risk of hazards, which seems to be to a bigger extent related with transformation than with preserving "the state of the system".

KEYWORDS: social resilience; resilience indices; social infrastructure, locality, culture of trust; local security; protection systems; resistance of systems

\section{INTRODUCTION}

The world is being rocked by hazards. The present pandemic situation has in particular revealed imperfections of systems and shortages in holistic management of societal resilience, but it is much more than that. It should be borne in mind that the catalogue of potential hazards is extensive and comprises an entire spectrum of threats that affect the functioning of communities. Security 
management is a specific process, which should take into account the building of societal resistance based on elasticity and flexibility of all its components. Since mid- $20^{\text {th }}$ century many debates, discussion and studies were dedicated to the concept of resilience. Many think the term has been coined by C. S. Holling in his breakthrough article from 1973 On the ecology of systems (Holling, 1973). At a time of intensifying hazards to security resilience as an ecological concept applied to associated man-environment systems (Berkes, 2007) may enable the formulation of new theories thanks to executing research and developing practical applications.

The coronavirus pandemic is seriously affecting the society. Pandemics may not be perceived as the only hazard, and so governments are aware of the fact that new crises would inevitably appear, the nature of which will be unforeseeable. This implies that assuring societal resilience is an obligation of utmost importance. Building and enhancing resilience requires counteracting shocks and the deployment of quick structural changes. The objective is to assure social well-being and integration of members of endangered communities. Well organised local measures will be conducive to transposing the thinking of resilience on elementary measures aimed at calming down the citizens, which need to be easy to implement. We are convinced that the SARS-CoV-2 pandemic that causes COVID-19 creates favourable conditions that may allow new openings in all fields of human life and perceiving the surrounding reality from a new perspective. For the moment the world has stopped, and the virus has infected the system which is waiting to be restarted so that we can begin to think of tomorrow. It is then that our thinking would be formatted, similarly as a computer hard disk. To quote Olga Tokarczuk, the Polish Nobel prize winner, the virus reminded us that we are fragile beings, built of the most fragile material, not separated from the rest of the world by our "humanity" and uniqueness. That the world is a kind of an extensive net, in which we have become entangled, connected with other beings by invisible threads of dependencies and influences. That regardless of how distant our countries of origin may be, what languages we speak, what the colour of our skin is, we contract the same illness and share the same fears; we die the same death. It made us aware that regardless of how weak and defenceless we may feel in a situation of threat, we are surrounded by people who may be even more defenceless than 
us, for whom our assistance is indispensable (Tokarczuk, 2020). The quality of a community is measured by those members who may be considered its most vulnerable element. Bauman compares the quality of a community to the load bearing capacity of a bridge, which is measured not by the average strength of support members, but rather the strength of the weakest member (Bauman, 2010). It is the resilience of the weakest members that affects the general ability of coping with a hazard and functioning in a reality after the disappearance of such a hazard.

It is vital to be able to transform monotony and routine, which may generate errors and loss of control over appearing hazards, into a flexible operating model, resistance to shock. It may be presumed that the time of the pandemic is an extraordinary situation, when the existing systems, the social framework, tend to lose control and are no longer capable of maintaining order, while new systems, established to be able to handle new conditions and circumstances, still remain in the planning phase, not devised yet, not fully finished, insufficiently robust to be able to cope with the entrusted tasks. Despite such changeable conditions, it is tremendously important to take swift actions, determined and prudent, as well as to activate the implementation process of the proposed solutions on all levels and within the widest possible group of involved actors (Berkes et al., 1998, Carpenter et al., 2001, Gunderson et al., 2005). Contemporarily the concept of resilience has gained particular importance, and its social definition as a "new and crucial element of humanitarian and developmental measures" (Department for International Development UK) should be adopted as quickly as possible as a central point of the approach taking into account the need of strengthening unstable systems of the contemporary world.

\section{MAterials AND METHODS}

It seems that in the resilience building process of key importance are analyses of available means and resources identified prior to the incident that are to be used to prevent and minimise losses related to the threats. This also comprises readiness and operating strategies following the incident (Cutter et al., 2008). 
For needs of the research process a definition of resilience has been adopted that is currently used in limiting the disaster risk, which is as follows: "Capacity of a system, community or society exposed to hazards to resist, absorb, adapt to consequences of a hazard and overcome difficulties on time and in an effective way, among others by preserving and restoring its elementary structures and functions" (UNISDR, 2009). With this in mind we may say that components of the process comprise rebound, adapt, overcome and maintain integrity. On the one hand we have purely technical definitions that allow measuring and monitoring of resilience (Manyena, 2006), and on the other hand the conviction that the most useful way of identifying resilience is having it defined as a capability (Bahadur, 2010, Norris et al., 2007) to cope with unfavourable changes and shocks, ability to "resist, regenerate or become adapted to consequences of the shock or change" (Mitchell et al. 2012).

Resilience becomes a part of both theory and practice, and not only enables foreseeing changes and crises, responding to them, survival without harm, and even increasing the potential after a crisis, but just as well opens a path to sustainable evolution, self-transformation and self-repair of societies. Basing on reference to the resilience of a given entity to its capability to absorb shocks and strains and to become a catalyst for restoration, adaptation, transformation and innovation (Béné et al., 2012), it may be worthwhile to adopt the concept of an individual and the structural field as a social network (Sztompka 2002) of a full concept of the essence of the society, i.e. the synergy that arises from anchoring entities in a structure and structures dependent on them. For this reason when studying resilience it is necessary to take into consideration the existing functional and organisational structures, normative and cultural systems, systems of security and goods distribution, social relations and interaction networks, as well as critical infrastructure systems along with individuals incorporated into those structures, forming not only single beings, but also groups and communities, which contribute to the structure gaining dynamics and which make the field remain in constant motion. This perpetual variability of the social life is in a paradox way the only constant element that sets out operating frameworks. The framework necessary to allow the preservation of social identity is cultivation of historical continuity and contemporarily the ability to draw appropriate conclusions from it and update 
its interpretations. The smallest segment of the individual and structural area is a social event (Sztompka 2002), identified as operation of an individual or of another defined entity undertaken in given structural conditions. Events form sequences. Their adaptation to changing circumstances makes them a driving force of the community. It is considered that this type of society is capable of self-transformations, where subjectivity is an outcome of skills, abilities, motivations, knowledge, ambition and dedication of community members, as well as structural conditions of those activities. If those features occur sufficiently frequently, they build more active communities, which are able to self-transform, which incessantly do their best to overcome barriers and handle challenges. On the other hand, communities with no such features are characterised by passiveness, stagnation, lack of motivation to act and inability to transform (Sztompka 2002). To be able to effectively adopt processes aimed at seeking resilience, it is necessary to first identify and define criteria for elementary determinants of resilience in a community.

To enhance the search for resilience, it is necessary to define the climate of trust (Sztompka 2007), which during long-term and purposeful action of humans becomes transformed into a culture of trust. In short, this phenomenon, which has been described by the recognised Polish sociologist Sztompka, consists of sets of conditions grouped in three components. The first component, one that already exists and is non-modifiable, is the history of the given entity (area, facility, space, community) as a background for the operation of individuals in structural systems that take into account the ontological order. If we do consider this in relation to a community, this would become understood as a set of factors generated by its fate and experience. The collective identity of a community is created by a clash of the present with the past. The successive set of conditions is comprised by the context of current social life. This is a type of a structural backbone, which combines the life of an individual, consisting of the existing normative cohesion, durability of the social order, clarity of societies and organisations, familiarity, responsibilities of people and institutions. The third tier, which assures dynamics to the process of community development, is constituted by people. Individuals in their perfect form of a resilient being anchored in a culture of trust are characterised by moods that comprise the ability to propagate the trust impulse, activism, optimism, orientation on the future and 
high aspirations, i.e. features that determine communities able of self-determination, repair, self-transformation and self-adaptation to the changing reality. This is a collective social capital, synergy worked out by intensifying mutuality and trust. Variables of social capital, which also include education, property, family support, relations with friends, having friends, health, religiousness etc. (Sztompka 2016), are perceived as a basis for establishing a stable, happy and healthy society. And in such a way the concept of resilience has become embedded in sociology in the context of resilient communities (Adger, 2000).

A review of literature of the subject has proven to the researchers that it is indeed worthwhile to seek variables that determine resilience among tangible and intangible resources, local mechanisms aimed at preserving the well-being of a community in situations of dynamic environmental, social and economic changes (Folke et al., 2003). Once they have received the catalogue of indices, local authorities along with everyday life actors should selected those that are most likely to allow management of combined human and natural systems by their analyses and a comparison with local conditions, and the social, cultural and environmental context (Erns, 2012). Data developed on the basis of indicators may prove to be helpful in assessing resources having a potential impact on the community's response to a hazard, on the feeling of security, responsibility, identity and acceptance.

\section{METHODOLOGY OF IDENTIFYING RESILIENCE INDICES OF LOCAL COMMUNITIES}

The key to the methodology of selecting appropriate indices is to identify priority elements of resilience of each community and consult them with local decision makers, community members, local non-government organisations and services.

Local resilience indicators comprise security systems, subsystems and actors, but also social and cultural and environmental elements, along with their ability to respond to shocks or disruptions. Providing reliable data, both qualitative and quantitative, which fully illustrate the complexity of the phenomenon, requires defining indices of trends for needs of monitoring changes 
in complex systems and between them, as well as identification of stabilisation processes and factors of positive or adverse changes.

Sets of indices may be used to measure:

- resources of individuals, including measures of relations and social elements and the use of economic indices based on the gross domestic product (GDP)-(measure of well-being);

- resources of organisational, legal, managerial, political and other systems.

It should be borne in mind that the indices may be considered a starting point for further discussions and analyses, and do not assure accurate resilience measurements.

When working out definitions of indices meant to measure societal resilience in the context of security, the research team made use of indices developed by international organisations, such as the United Nations University Institute for the Advanced Study of Sustainability (UNU-IAS )-SEPLS (Folke et al., Townshend et al., 2015, Adger et al., 2000, Hollnagel, 2011, Berkes et al., 2013). Furthermore, when defining a society as an individual and structural field, the most extensive possible scope of issues has been adopted, including the culture of trust.

The performed analyses allowed establishing a catalogue of indices, which was subjected to verification and testing in the research process on the basis of individual surveys (Babbie, 2003). In the opinion of the authors this form of qualitative surveys has proven to be optimum in social surveys. The participants do not form a statistical representation of any specific population, and that allows selecting respondents according to the key adopted for the trial. Individual surveys based on a form enable studies of the above mentioned issues (Morgan, 1993).

Surveys were carried out among representatives of the State Fire Service and the Voluntary Fire Service as services that operate in the field of security, quite frequently of a leading nature during the elimination of hazards, and also active members of local communities. The survey has been carried out in the Łomianki municipality close to Warsaw, with Łomianki serving as an illustrative municipality exposed to a classical range of hazards that comprise: floods, inundations, fires, road accidents, acts of vandalism, muggings, thefts etc. 
The participants were asked to relate to the proposed indices and questions that allow their measurable definition. Validation of the tool designated to verify resilience carried out during the interviews enabled the preparation of a catalogue of indices, which was then assessed by local decision-makers in the third stage of studies. 


\section{RESULTS}

During the research process a catalogue of indices has been established, along with questions and topics to help compiling data to analyse the flexibility/resilience of the studied community.

The below tables presents the developed indices.

Table 1

Indices and questions used to identify them-Diversity of security systems

\begin{tabular}{|l|l|}
\hline \multicolumn{1}{|c|}{ Indices } & \multicolumn{1}{c|}{ Questions for identification } \\
\hline $\begin{array}{l}\text { Diversity } \\
\text { of security } \\
\text { subsystems/ } \\
\text { actors/ systems. }\end{array}$ & $\begin{array}{l}\text { Formalisation of the security system; } \\
\text { Diversity of subsystems; } \\
\text { Correct operation of systems /subsystems; } \\
\text { Human resources used to develop systems and subsystems; } \\
\text { Capital resources used to develop systems and subsystems; } \\
\text { Resources of actors involved in systems / subsystems; } \\
\text { Competencies of actors involved in functioning of systems; }\end{array}$ \\
\hline $\begin{array}{l}\text { Protection } \\
\text { of systems } \\
\text { (components) }\end{array}$ & $\begin{array}{l}\text { Protection of systems in a formal/informal way } \\
\text { Familiarity with protection of security system entities } \\
\text { Monitoring level of system protection } \\
\text { Level of usage of previous experience in ways of system protection } \\
\text { Existence of a defined catalogue of potential factors that affect the } \\
\text { system output } \\
\text { Protection level of resources used in operation of the systems } \\
\text { Identification of the weakest links of systems } \\
\text { Protection level of the weakest links of systems }\end{array}$ \\
$\begin{array}{l}\text { Recovery and } \\
\text { regeneration } \\
\text { between systems / } \\
\text { components of the } \\
\text { security system }\end{array}$ & $\begin{array}{l}\text { Level of interaction between systems (If so, what type and in which } \\
\text { situations?) } \\
\text { Information flow level } \\
\text { Joint obtaining of information } \\
\text { Cooperation to allow joint learning and drawing correct conclusions } \\
\text { from appropriate experiences } \\
\text { Availability of systems for common citizens }\end{array}$ \\
\hline $\begin{array}{l}\text { Existence of plans on methods of restoring a system/a subsystem; } \\
\text { Functioning of a mechanism of learning from committed mistakes; } \\
\text { Functioning of formalised and/or non-formalised regeneration } \\
\text { methods; } \\
\text { Level of ability to regenerate after extreme shocks (time/source of } \\
\text { supplementing forces and means) }\end{array}$ \\
\hline
\end{tabular}

Source: own study 
Table 2.

\section{Indices and questions used to identify them-Social diversity}

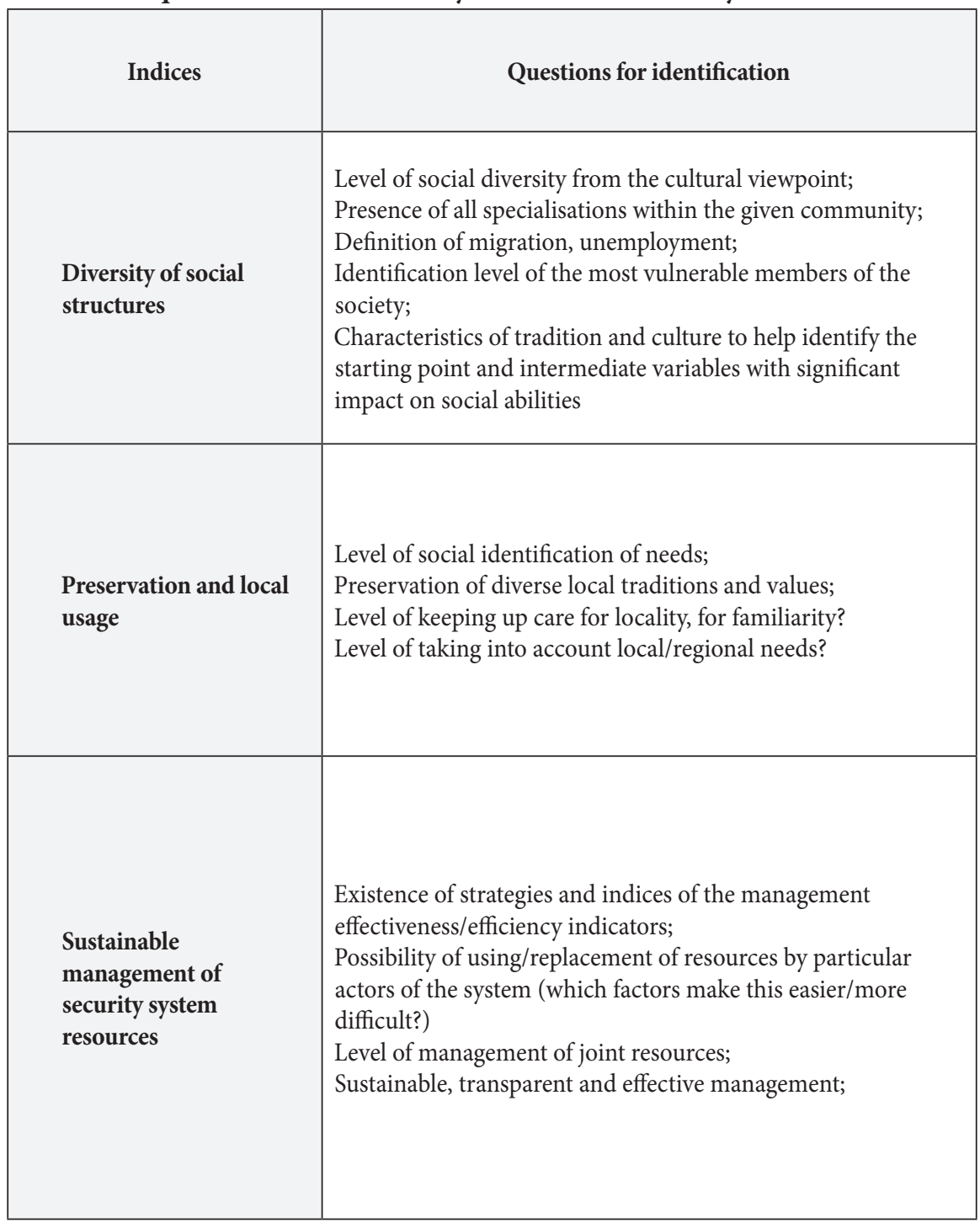

Source: own study 
Table 3.

\section{Indices and questions used to identify them-Knowledge and innovations}

\begin{tabular}{|c|c|}
\hline Indices & Questions for identification \\
\hline $\begin{array}{l}\text { Innovations in the } \\
\text { security system }\end{array}$ & $\begin{array}{l}\text { Level of working out, improving and adopting of new } \\
\text { preventive practices and of responding by becoming prepared } \\
\text { for dynamic conditions; } \\
\text { Degree of advancement of works on new solutions; } \\
\text { Implementation of new solutions; } \\
\text { Degree of benefitting from solutions in other regions; }\end{array}$ \\
\hline $\begin{array}{l}\text { Acquired knowledge } \\
\text { related to systems }\end{array}$ & $\begin{array}{l}\text { Utilisation level of local knowledge and cultural traditions } \\
\text { in the creation of new ones, monitoring of current ones and } \\
\text { upgrading security systems; } \\
\text { Degree of knowledge formalisation and upgrading; } \\
\text { Knowledge based on learning on experience; }\end{array}$ \\
\hline $\begin{array}{l}\text { Documentation of } \\
\text { diversity }\end{array}$ & $\begin{array}{l}\text { Level of documenting the complexity of societies and of } \\
\text { systems/subsystems/security entities; } \\
\text { Level of their support with research, analyses and comparisons; }\end{array}$ \\
\hline Knowledge of women & $\begin{array}{l}\text { Degree to which knowledge, experience and abilities of women } \\
\text { are respected on various levels; } \\
\text { Degree of unevenness and discrimination in this respect; }\end{array}$ \\
\hline
\end{tabular}

Source: own study 
Table 4.

\section{Indices and questions used to identify them-Social management and justice}

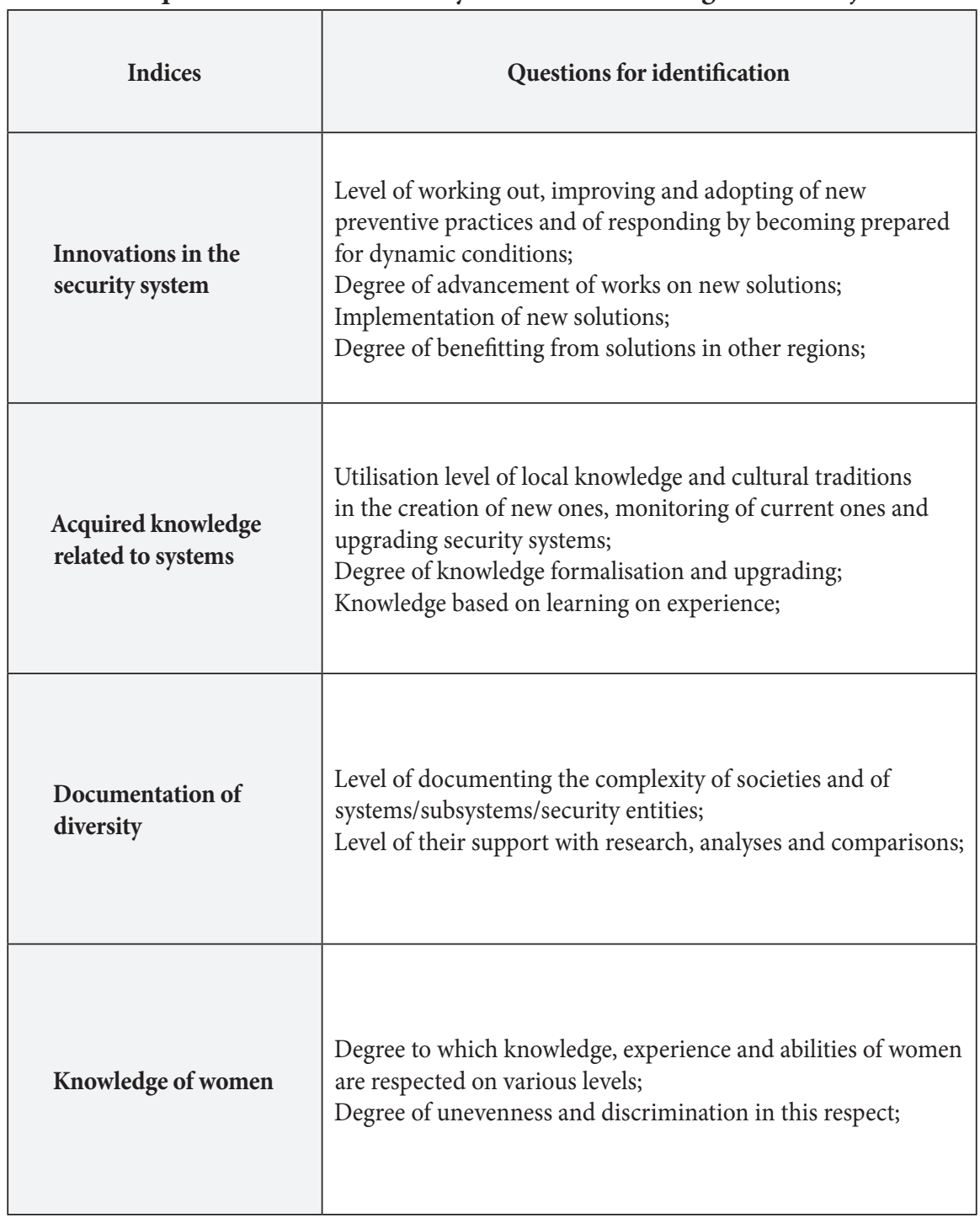

Source: own study 
Table 5.

Indices and questions used to identify them-Livelihood and well-being

\begin{tabular}{|c|c|}
\hline Indices & Questions for identification \\
\hline $\begin{array}{l}\text { Social and economic } \\
\text { infrastructure }\end{array}$ & $\begin{array}{l}\text { Level of adequacy of social and economic infrastructure in } \\
\text { relation to the needs; } \\
\text { Level of verification of adequacy; } \\
\text { Updating taking into account changing needs; }\end{array}$ \\
\hline $\begin{array}{l}\text { Human health and } \\
\text { environmental } \\
\text { conditions }\end{array}$ & $\begin{array}{l}\text { General health-related situation of the local population, also } \\
\text { taking into account the prevailing environmental conditions; } \\
\text { Maintained environmental balance; }\end{array}$ \\
\hline Diversity of income/costs & $\begin{array}{l}\text { Involvement of the community in various sustainable revenue } \\
\text { generating activities; } \\
\text { Level of generated revenue; } \\
\text { Level of permanent income received by the community to } \\
\text { allow it to reach its goals; } \\
\text { Existence of other forms of revenue generation beyond } \\
\text { material income; }\end{array}$ \\
\hline $\begin{array}{l}\text { Livelihood based on } \\
\text { cultural and economic } \\
\text { diversity }\end{array}$ & $\begin{array}{l}\text { Level of development of innovative usage of local cultural and } \\
\text { economic diversity in a society; }\end{array}$ \\
\hline $\begin{array}{l}\text { Social and economic } \\
\text { mobility }\end{array}$ & $\begin{array}{l}\text { Changes to the social and economic status between } \\
\text { generations and within individual generations; } \\
\text { Conditions for economic and social mobility; } \\
\text { Monitoring and analysing those conditions; }\end{array}$ \\
\hline
\end{tabular}

Source: own study 
Table 6.

\section{Indices and questions used to identify them-Culture of trust}

\begin{tabular}{|l|l|}
\hline \multicolumn{1}{|c|}{ Indices } & \multicolumn{1}{c|}{ Questions for identification } \\
\hline \multirow{5}{*}{$\begin{array}{l}\text { Existing normative } \\
\text { cohesion }\end{array}$} & $\begin{array}{l}\text { Trust in administrative bodies, } \\
\text { Feeling of cohesion, } \\
\text { Familiarity with common norms, } \\
\text { Level of identification with them } \\
\text { Possibility of participating in the creation of local norms and } \\
\text { rules; } \\
\text { Preservation of historical identity with participation of in- } \\
\text { volved community, e.g. allowing for standards of honesty and } \\
\text { reliability; }\end{array}$ \\
\hline \multirow{5}{*}{$\begin{array}{l}\text { Durability of social } \\
\text { order }\end{array}$} & $\begin{array}{l}\text { Feeling of security, good attitude, trust in non-government } \\
\text { organisations, neighbours } \\
\text { Availability of a stable point of reference that allows sustaina- } \\
\text { ble functioning of entities that surround it }\end{array}$ \\
\hline \multirow{2}{*}{$\begin{array}{l}\text { Familiarity } \\
\text { organisation }\end{array}$} & $\begin{array}{l}\text { Access to information, } \\
\text { Level of setting up of cooperation mechanisms; } \\
\text { Trust in the local media; } \\
\text { Differentiation of the media; }\end{array}$ \\
\hline
\end{tabular}

Source: own study

We suggest to have the above set of indices ordered in accordance with abilities that are indispensable for flexible activity (Hollnagel, 2011). Assessments of particular indices will help us get an image of the resilience of the community being studied. Matching of indices to the given capability may be subject to internal local modifications, yet in general terms they are contained within four features: responding, monitoring, learning and forecasting. 
1. Ability to respond. Knowledge what to do. Capability of responding to regular and irregular changes, disruptions and opportunities by activating prepared activities or adaptation of the hitherto mode of functioning. Having tangible and intangible resources and their appropriate utilisation.

\section{Indices:}

Diversity of subsystems/actors/security systems; Interactions between systems / components of the security system; Preservation and local usage; Sustainable management of security systems resources; Acquired knowledge pertaining to systems; System based on a civil society; Existing normative cohesion;

2. Ability to monitor. Knowledge what to search for and what should be monitored. Possibility of monitoring all elements which affect or which could seriously affect (positively or adversely) the effectiveness of the system. Monitoring must comprise own operation of the system, as well as everything that takes place in the environment, so that it remains sensitive and ready to any adverse stimuli coming from the environment.

\section{Indices:}

Protection of systems (components); Innovations in the security system; Laws pertaining to systems/subsystems, communities, management of resources which may be drawn from; Durability of social order; Clarity of social organisation;

3. Ability to learn. Knowing what has happened. Ability of learning on the basis of experience, in particular drawing correct conclusions from the appropriate experience.Indices: Recovery and regeneration; Diversity of social structures; Knowledge of women; Social capital consisting of cooperation in the entire region/community; Livelihood based on cultural and economic diversity; Social and economic mobility; Familiarity; Existing normative cohesion; Social equality;

4. Ability to foresee. Knowing what to expect. Ability to foresee changes in the further future, such as potential disruptions, new requirements or limitations, new possibilities or changing operating conditions (Hollnagel, 2011). 


\section{Indices:}

Documentation of diversity; Human health and environmental conditions; Responsibility both of people and institutions; Social and economic infrastructure; Diversity of income/costs;

The received responses make it possible to ascribe values to indices in a 7-step scale, which will enable obtaining information on the present situation in selected capabilities of resilience. Such studies in which use is made of the proposed indices may prove to be helpful in diagnosing systemic shortcomings, obtaining mutual understanding of potential hazards, identifying weak points of systems and subsystems and the efficiency of security actors. All this is meant to propose solutions and to allow defining strategies of building and reinforcing of resilience.

Regular application of the pattern of indices at specific time intervals, such as for example a quarterly or semi-annual assessment of resilience, would most likely enable effective monitoring of changes in security systems or entities. Radar diagrams (fig. 1 and 2) may be used to show which individual values of indices affect the system / security of the subject's resilience and how trends change when trials are repeated (table 7) (UNU-IAS, 2014).

Table 7.

7-step scale along with ascribed trends

\begin{tabular}{|l|l|}
\hline Scale & \multicolumn{2}{|c|}{ Trend } \\
\cline { 1 - 1 }$[7]$ maximum & \multirow{2}{*}{ uptrend } \\
\cline { 1 - 1 }$[6]$ very high & \\
\cline { 1 - 1 }$[5]$ high & unchanged \\
\cline { 1 - 1 }$[4]$ average & \multirow{2}{*}{ downtrend } \\
\cline { 1 - 1 }$[3]$ low & \\
\cline { 1 - 2 }$[2]$ very low & \\
\cline { 1 - 1 }$[1]$ zero & \\
\hline
\end{tabular}

Source: own study

The values ranging from 1 to 7 ascribed in line with the adopted methodology to particular elements that identify the index will allow achieving a resilience index that is demonstrable (table 7). 
Figure 1.

\section{Radar diagram of values for abilities of responding}

Diversity of

subsystems/actors/security

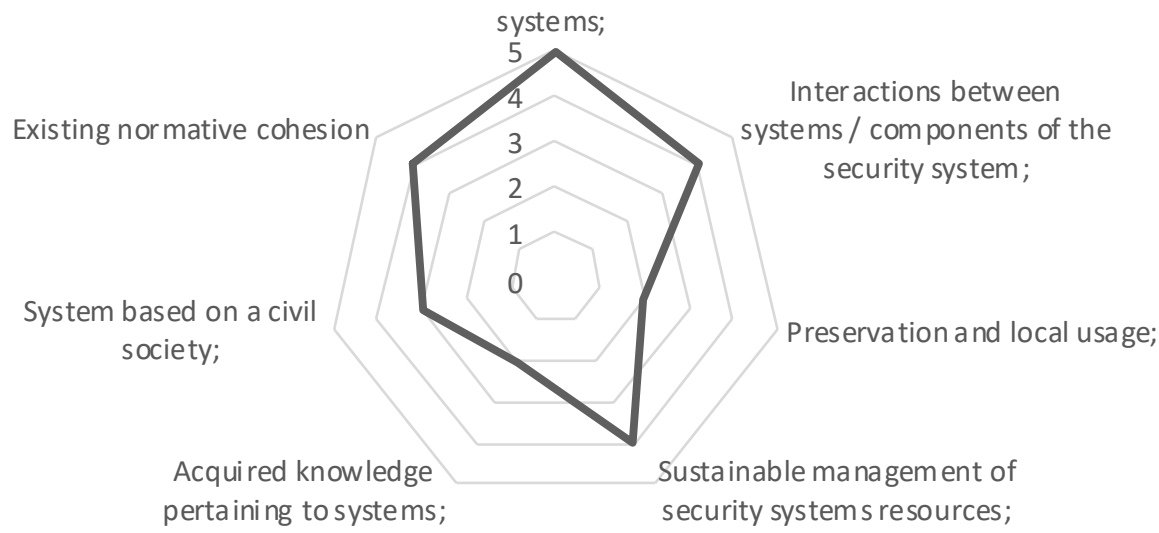

Source: own study

Figure 2.

\section{Radar diagram after 6 months of responding abilities}

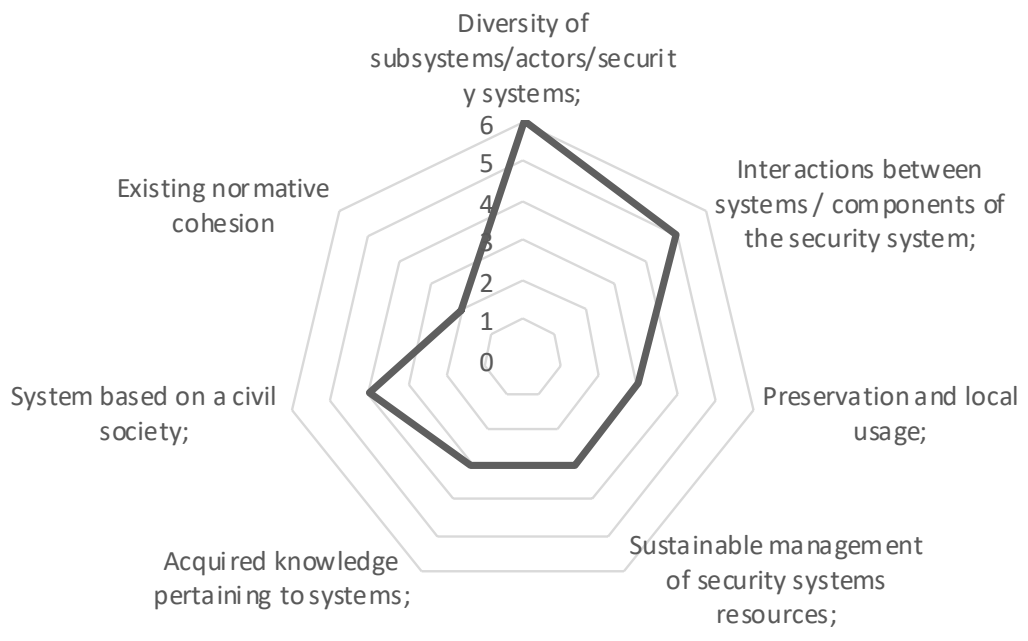

Source: own study 
Using statistical deduction (e.g. logistic regression) we will be able to prove dependencies that exist between the analysed variables.

Table 8.

Resilience in four scopes of abilities with a specification of location or variability

\begin{tabular}{|c|c|c|c|c|}
\hline \multirow{2}{*}{} & \multicolumn{2}{|c|}{ Mean arithmetic value } & \multicolumn{2}{c|}{ Standard deviation } \\
\cline { 2 - 5 } & presently & after 6 months & presently & after 6 months \\
\hline Ability of responding & 3.22 & 3.44 & 1.31 & 1.39 \\
\hline Ability of monitoring & 3.13 & 3.5 & 1.64 & 1.31 \\
\hline Ability of learning & 2.13 & 0.99 & 2.63 & 0.74 \\
\hline Ability of foreseeing & 2.63 & 1.41 & 3.25 & 1.16 \\
\hline
\end{tabular}

Source: own study

If statistical deduction is adopted (e.g. logistic regression), it will enable the identification of dependencies between the analysed variables.

\section{Discussion}

The obtained results allow to blend in into discussions as to what is comprised by the term of resilience and to supplement the catalogue of measures, variable that are determinant for societal resistance. The concept of resilience that comes up in sociology (Adger, 2000) may be well deployed into the sciences on security as definitions of resilient and flexible communities.

It is worth taking into account the ability of communities to become adapted to extreme environmental conditions. In this respect worthy of attention is the definition of resilience coined by Rankine which was used by him to describe resilience and deformation of steel beams (Rankine, 1867) and which has initiated the contemporary use of this term in civil protection. Resilience and the ability of absorption as well as elasticity serve as forces of a society in a state of crisis. The ability to have means suitable to oppose a disaster and maintain its integrity/cohesion as well as the plasticity to become adapted to changing circumstances (Alexander, 2012) serves as a starting point for establishing a catalogue of indices. (Klein et al. 2003) went even so far as to state that the preservation and strengthening 
of adaptation capabilities should be perceived to be a general objective of resilience. Such capabilities may only be feasible if factors are identified and systematised, as has been done in the present study. The devised indices, which in the opinion of researchers define resilience, may be applied to any given phenomenon associated with shock, either physical or societal, and regardless of the fact whether the shock gives rise to disasters, or whether it is a strong impact in a literal and figurative way. Resilience is perceived as a promising response to recurring difficulties in risk management (Magali et al., 2012). Categories of indices generated during the research process reflect spheres of relations and dependencies between systems, subsystems on the one hand and resources and knowledge on the other. They also emphasise the importance of managing communities, structure and processes. Apart from those forms, the respondents also stated the necessity of diversity and the trust climate which is conducive to building societal resistance. A resilient community must have jointly considered decision-making processes coordinated with actions (K.Tierney, 2012) sustainable management of social and natural resources and promotion of sustainable social development (et al., 2005, Ahrens et al., 2006)

Worthy of emphasis is the relation of effective management with the way that people perceive trust, inclusivity and the effective role of leaders (Purdue, 2001). The fact whether people trust decision-makers (Paton, 2007) (Paton, 2008), feel their involvement into decision-making processes (J Newport, 2003), and trust the effectiveness and competitiveness of the leaders [Rubin, 1985 ) is of utmost importance in the process of shaping abilities.

Despite omnipresent hazards, the growing number of fatalities and the ensuing financial costs, operating strategies still tend to focus on the physical infrastructure, among others on reinforcing flood dykes, restoration of existing structures and repair of those that had sustained damage despite there being evidence that it is the social infrastructure, and not the physical one, that enhances resilience (Aldrich, 2015). This explains the great importance of identifying the social infrastructure, which is feasible thanks to the use of developed indices. 


\section{Conclusion}

The goal of the present paper was to present the authors' idea concerning the working out of tools for well-defined and correct analyses of the issue of societal resilience in the context of sustainable development to assure security with emphasis on social infrastructure. The above described process has enabled the establishment of the catalogue of indices. This research framework assures a local measure of societal resilience being a condition for sustainable development. It has been designed in a universal way, allowing a possibility of assuring reproducibility and objectivism of assessment. In the subsequent stage of the studies it will be possible to verify whether the indices have been selected appropriately, as well as their completeness and adequacy.

Experts are of the opinion that resilient behaviour comprises learning from past or present disruptions. This helps the societies on the one hand to improve their resilience abilities, and on the other hand to reduce risk at a later time. In this context the potential hazard of extended pandemic disruption may be perceived as an occasion for progress and making a great leap forward. We are obligated to comprehend that the COVID-19 crisis may be an occasion for quick changes and growth - in other words - a stimulus that could enhance our resilience. 


\section{REFERENCES}

Berkes, F. (2007). Understanding uncertainty and reducing vulnerability: lessons from resilience thinking. Nat Hazards 41. https://doi.org/10.1007/s11069-006-9036-7.

Adger, W. N. (2000). Social and ecological resilience: are they related? Progress in Human Geography 24(3). https://doi.org/10.1191/030913200701540465.

Adger, W. N., Arnell, N. W., Tompkins, E. L. (2005). Successful adaptation to climate change across scales. Global Environmental. Change 15(2). http://dx.doi.org/10.1016/j. gloenvcha.2004.12.005.

Adger, W. N., Hughes, T. P., Folke, C., Carpenter, S. R., Rockstrom J. (2005). Socialecological resilience to Coastal disasters. Science 309. http://dx.doi.org/10.1126/ science.1112122.

Ahrens J., Rudolph P. M. (2006). The importance of governance in risk reduction and disaster management. Journal of Contingencies Crisis Management 14(4). https:// doi.org/10.1111/j.1468-5973.2006.00497.x.

Aldrich, D. P., Meyer, M. A. (2015). Social Capital and Community Resilience. American Behavioral Scientist, 59(2). doi: 10.1177/0002764214550299.

Babbie, E. (2003). Badania społeczne w praktyce, PWN.

Bahadur, A. V., et al. (2010). The resilience renaissance? Unpacking of resilience for tackling climate change and disasters. Strengthening Climate Resilience Discussion. Brighton: IDS. https://opendocs.ids.ac.uk/opendocs/handle/20.500.12413/2368.

Bauman, Z. (2010). Socjalizm potrzebny od zaraz. Le Monde diplomatique, 55(9).

Béné, Ch., Wood, R. G., Newsham A., Davies M. (2012). Resilience: New Utopia or New Tyranny? Reflection about the Potentials and Limits of the Concept of Resilience in Relation to Vulnerability Reduction Programmes. https://doi.org/10.1111/j.20400209.2012.00405.x.

Berkes, F., Folke, C. (1998). Linking social and ecological systems for resilience and sustainability. Cambridge University Press.

Berkes, F., Ross, H. (2013). Community Resilience: Toward an Integrated Approach. Society \& Natural Resources, 26 (1). doi:10.1080/08941920.2012.736605.

Carpenter, S., Walker, B., Anderies, J. M., Abel, N. (2001). From Metaphor to Measurement: Resilience of What To What? Ecosystem, 4(8). https://doi: 10.1007/ s10021-001-0045-9.

Cutter, S., Barnes, L., Berry, M., Burton, C., Evans, E., Tate, E., Webb, J. J. (2008). A place-based model for understanding community resilience to natural disasters. Global Environmental Change-human and Policy Dimensions, 18.

Department for International Development UK.

Erns, E. (2012). Conducting Two-Way Ecological Research, In People on Country: Vital Landscapes. Indigenous Futures, ed. J. C. Altman, S. Kerins. Sydney. Federation Press. 
Folke, C., Colding, J., Berkes, F. (2003). Synthesis: Building Resilience and Adaptive Capacity in Social-Ecological Systems, in: Navigating Social-Ecological Systems: Building Resilience for Complexity and Change. Cambridge University Press, doi:10.1017/CBO9780511541957.020.

Gunderson. L., Folke, C. (2005). Resilience-now more than ever-Ecology and society, 10(2). JSTOR URL: http://www.ecologyandsociety.org/vol10/iss2/art22.

Holling, C. S. (1973). Resilience and Stability of Ecological Systems. Annual Review of Ecology. Evolution and Systematics, 4.

Hollnagel, E. (2011). RAG - The resilience analysis grid, in: Hollnagel, E., Pariès, J., Woods, D. D., Wreathall, J. (Eds). Resilience Engineering in Practice. A Guidebook. Farnham. UK: Ashgate.

Manyena, S. B. (2006). The concept of resilience revisited. https://doi.org/10.1111/j.0361666.2006.00331.x; 30 (4).

Mitchell, T., Harris, K. (2012). Resilience: A risk management approach. ODI Background Notes.

Morgan, D. (1993). Successful Focus Groups: Advancing the State of the Art. SAGE Focus Editions. https://dx.doi.org/10.4135/9781483349008.

Newport, J. K., Jawahar, G. G. P. (2003). Community participation and public awareness in disaster mitigation. Disaster Prev Manag An Int J 12. https://doi. org/10.1108/09653560310463838.

Norris, F. H., Stevens, S. P., Pfefferbaum, B., Wyche, K. F., Pfefferbaum, R. L. (2007). Community Resilience as a Metaphor, Theory, Set of Capacities, and Strategy for Disaster Readiness. American Journal of Community Psychology 41. https://doi. org/10.1007/s10464-007-9156-6.

Paton, D. (2008). Risk communication and natural hazard mitigation: how trust influences its effectiveness. International Journal of Global Environmental Issues. Inderscience Enterprises Ltd, vol. 8(1/2).

Paton, D. (2007). Preparing for natural hazards: the role of community trust. Disaster Prevention and Management, Vol. 16 No. 3. https://doi. org/10.1108/09653560710758323.

Purdue, D. (2001). Neighbourhood governance: leadership, trust and social capital. Urban Studies 38(12). https://doi.org/10.1080/00420980120087135

Rankine, W. J. M. (1876). A Manual of Applied Mechanics. Charles Griffin and Co. London.

Reghezza-Zitt, M., Rufat, S., Djament-Tran, G., Le Blanc A., L'Homme, S. (2012). What Resilience Is Not: Uses and Abuses. Cybergeo: Revue européenne de géographie / European journal of geography. UMR 8504 Géographie-cités, (10.4000/ cybergeo.25554). (halshs-01210140). 
Rubin, C. B., Saperstein, M. D., Barbee, D. G. (1985). Community recovery from a major natural disaster. FMHI Publications. https://scholarcommons.usf.edu/fmhi_pub/87 Sztompka, P. (2016). Kapitał Społeczny. Teoria przestrzeni międzyludzkiej. Znak. Kraków Sztompka, P. (2002). Socjologia. Znak. Kraków.

Sztompka, P. (2007). Zaufanie, Fundament społeczeństwa. Znak. Kraków.

Tierney, K. (2012). Disaster governance: social, political, and economic dimensions, Annu. Rev. Environ. Resour. 37(1). http://dx.doi.org/10.1146/annurev-environ-020911-095618.

Tokarczuk, O. (2020). Okno. Feuilleton in Frankfurter Allgemeine Zeitung. https:// www.faz.net/suche/?query=tokarczuk\&resultsPerPage $=20$ access 01/04/2020

Townshend, I., Awosoga, O., Kulig, J., et al. (2015). Social cohesion and resilience across communities that have experienced a disaster. Nat Hazards 76. https://doi. org/10.1007/s11069-014-1526-4.

United Nations International Strategy for Disaster Reduction (UNISDR). United Nations. Geneva. Switzerland. May 2009.

UNU-IAS, Bioversity International, IGES and UNDP. (2014). Toolkit for the Indicators of Resilience in Socio-ecological Production Landscapes and Seascapes (SEPLS). 